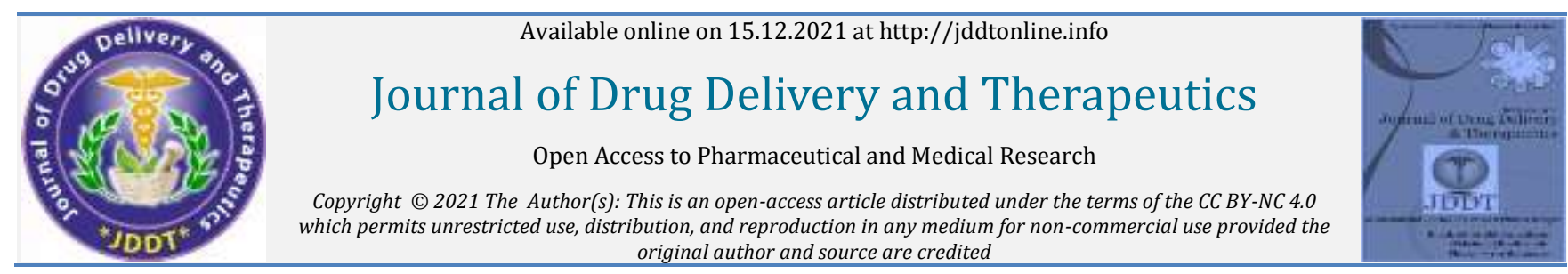
original author and source are credited
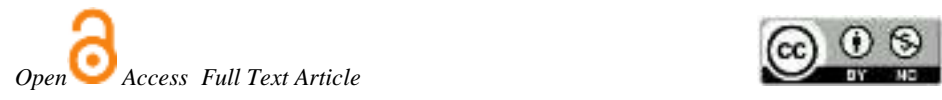

Research Article

\title{
Effect of Annonaceous Sp. Ethanolic Extract on Transforming Growth Factor- B (TGF- B) Expression on MCF-7 Cells Line
}

\author{
Muhartono ${ }^{1}$, Suharyani2 ${ }^{*}$, Asep Sukohar ${ }^{1}$, Arli Suryawinata ${ }^{1}$, Silvia Andriani2 \\ ${ }^{1}$ Faculty of Medicine, University of Lampung, Lampung 35141, Indonesia \\ ${ }^{2}$ Faculty of Mathematics and Natural Science, University of Lampung, Lampung 35141, Indonesia
}

Article Info:

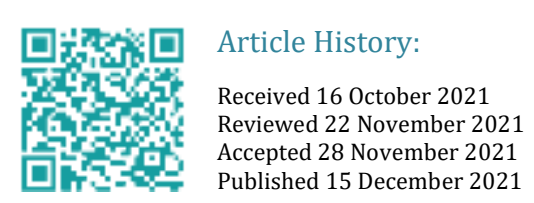

\section{Cite this article as:}

Suharyani, Muhartono, Sukohar A, Suryawinata A, Andriani S, Effect of Annonaceous Sp. Ethanolic Extract on Transforming Growth Factor- B (TGF- B) Expression on MCF-7 Cells Line, Journal of Drug Delivery and Therapeutics. 2021; 11(6-S):49-52

DOI: http://dx.doi.org/10.22270/jddt.v11i6-S.5214

*Address for Correspondence:

\section{Abstract}

\begin{abstract}
Aims: To analyze effect of the Annonaceous sp. ethanolic extract to Transforming Growth Factor- $\beta$ (TGF- $\beta$ ) expressions on MCF-7 cells line.

Methods: This experimental analytic study used Randomized Complete Block Design (RCBD) with three repetitions. The extract was dissolved in $1 \mathrm{ml}$ of DMSO with a concentration of $0.1 \%$. Furthermore, dilution was made with a dose of $0 \mu \mathrm{g} / \mathrm{ml}(\mathrm{K}) ; 25 \mu \mathrm{g}$ / $\mathrm{ml}$ (P1); $50 \mu \mathrm{g} / \mathrm{ml}$ (P2); $100 \mu \mathrm{g} / \mathrm{ml}$ (P3); $200 \mu \mathrm{g} / \mathrm{ml}$ (P4). MCF-7 cells line were cultured using RPMI 1640 Medium with $80-90 \%$ confluent. The ethanolic extract of Annonaceous sp. was exposed to MCF-7 cells for 48 hours. Analyze Transforming Growth Factor- $\beta$ (TGF- $\beta$ ) level using ELISA Methods with $\lambda=405 \mathrm{~nm}$.
\end{abstract}

Results: The results of the ELISA analysis show that the ethanolic extract of Annonaceous sp. has a potential effect of decreasing TGF- $\beta$ expression on the sample with treatment on some concentration $(\mathrm{p}<0,05)$.

Conclusion: The ethanolic extract of Annonaceous sp. has shown the potential effect to decreased of TGF- $\beta$ level on MCF-7 cells line

Keywords: Annonaceous sp ethanolic extract, TGF- $\beta$, MCF-7 cells line, anti-cancer

Suharyani, Department of Biology, Faculty of Mathematics and Natural Science, University of Lampung, Soemantri Brojonegoro Street No. 1, Gedung Meneng Bandar Lampung, Indonesia

\section{INTRODUCTION}

Cancer is the number one killer globally and has continuously increased in prevalence over the years and is also one of the leading causes of mortality worldwide. International Agency for Research on Cancer (IARC) in 2018 reported there were 18.1 million new cancer sufferers, with a mortality rate was 9.6 million. ${ }^{1,2}$

Breast cancer is the most common cancer among women and is one of the most important causes of death. WHO reported breast cancer incidence in 2018 is the most frequently diagnosed cancer among women, impacting $24 \%$ of all cases (2.1 million patients) with a mortality rate were $15 \%$ of the total. ${ }^{3}$ In Indonesia, breast cancer is the most frequently diagnosed cancer by $18,6 \%$ of relative frequency. While breast cancer rates are higher among women in more developed regions, rates increase in nearly every region globally. 4,5

Systemic breast cancer therapy has been conducted for the last hundred years since Beatson in 1896 demonstrated that ovarium ablation changes hormonal balancing in a woman with breast cancer. Breast cancer management is determined by the biomolecular or biomolecular-signaling agent's extent, stage, and expression. Moreover, the choice of chemotherapy or hormonal therapy for breast cancer patients depends on technological advancements such as immunohistochemistry and biomolecular assay. 4,6

The process of how breast cancer was initiated is still unknown. However, several hypotheses have emerged, such as inflammation has been proposed to mediate the initiation and promotion of tumors, angiogenesis, and metastasis of breast cancer. The inflammatory cells will be attracted by oncogenic changes, hypoxia condition, cytokines, and chemokines response, among other factors. Several cytokines like Interleukin (IL)-1, IL-6, IL-11, and transforming growth factor- $\beta$ (TGF- $\beta$ ) will regulate the inflammatory tumor microenvironment and stimulate cancer cell proliferation and invasion. ${ }^{7}$

TGF- $\beta$ is the most extensively studied cytokine in breast cancer. TGF- $\beta$ belongs to the TGF- $\beta$ superfamily and is a significant regulator of many processes, including proliferation, differentiation, migration, immunity, and apoptosis. TGF- $\beta$ has dual functions in tumor progression. As a tumor suppressor, it has antiproliferative effects in the 
early stages of tumorigenesis, but tumor cells in later stages evade this effect and progress in response to TGF- $\beta .^{7}$

Management of breast cancer also has some adverse effects. In addition, factors of age, co-morbid disease, evidence-based study, cost-effective utility, and when to stop the systemic treatment should be considered. Chemotherapy is a treatment using anti-cancer compounds by systemic used to suppress cell proliferation and trigger apoptosis. So that in use, chemotherapy cannot just focus on cancer cells but also affect other cells and cause decreased immune function due to adverse effects. ${ }^{8}$

For many years traditional herb medicines have been used as medical treatment, especially in developing countries. Plants have been used in medicine for their natural antiseptic properties. Many studies were seeking the potential activity compound and the uses of plants for the preparation of potential drugs, including cancer. There are about 40,000 plants in the world, and 30,000 have been reported found in Indonesia. Moreover, 940 of them have been utilized as traditional medicine. Medicinal herbs and their derivate phytocompounds are being increasingly recognized as useful complementary treatments for cancer. Currently, several plant-derived compounds have been successfully used as cancer therapy, such as vincristine and vinblastine isolated from Catharanthus roseus. Several studies of phytochemical compounds show that antioxidant and anti-inflammatory properties can inhibit tumor initiation, promotion, and progression - the most important in developing herbs as anti-cancer referring to standard quality, efficacy, and safety. Therefore, we need an analysis of the mechanism of herbs on a molecular level. 9,10,11

Annona muricata (Graviola) has been claimed for its potential against various diseases, including cancer. Graviola is a small deciduous tree of the Annonaceae family broadly distributed in tropical countries that is well known by several names, including Annona muricata, soursop, Brazilian paw, and guanabana, with more than 212 phytochemicals identified in the various extracts of Graviola found in fruits, seeds, bark, roots, and pericarp. The diverse constituents' metabolites of Graviola such as acetogenins are understood to play a central role in its anti-cancer properties on different human cell lines, as are many other constituents such as flavonoids, sterols, alkaloids, and others. ${ }^{12}$

Acetogenins (ACG) are naturally occurring compounds that are chemically one of the least investigated families. ACG is a very potent cytotoxic compound, targeting the reduced nicotinamide adenine dinucleotide (NADH): ubiquinone oxidoreductase (also known as complex I). NADH is a membrane-bound protein of the mitochondrial electron transport system and the ubiquinone-linked NADH oxidase in the plasma membrane of cancerous cells. Inhibition by these mechanisms results in adenosine triphosphate (ATP) deprivation, leading to apoptosis of the high energy demanding tumor cells. The acetogenins are now considered the most potent (effective in nanomolar concentrations) known inhibitors of the mitochondrial complex I. More recently, annonaceous acetogenins have also been shown to overcome resistance in multidrug-resistant (MDR) tumors. ${ }^{13,14}$

Angiogenesis is an essential step for breast cancer progression and dissemination. The development of new blood vessels in a cancer setting (angiogenesis) is conducted by numerous physiological and pathological stimuli, where the primary stimulus is hypoxia. Molecular players of angiogenesis have been characterized since the early years of angiogenic studies, and one of the most prominent stimulating growth factors is the vascular endothelial growth factor family. ${ }^{15,16}$

Transforming growth factor (TGF)- $\beta 1$ is a cytokine involved in immune suppression, angiogenesis, apoptosis, cell growth, and epithelial to mesenchymal transitions (EMTs) during carcinogenesis. In early tumorigenesis, TGF- $\beta 1$ has the growth of epithelial cells, and insensitivity to this growth inhibitory effect was associated with tumor progression. However, in later stages, TGF- $\beta$ has a contrast effect with a promoter of tumor cell invasion and metastasis effect in tumorigenesis. Increased production of TGF- $\beta 1$ was observed in breast cancer compared with normal tissues. One mechanism by which TGF- $\beta 1$ can promote tumor cell motility and invasion is through the induction of EMT. EMT is a complex process that involves changes in cell morphology and dissociation of cell-cell contacts lead to tumorigenesis. ${ }^{17}$

\section{MATERIAL AND METHOD}

\section{Study Design}

This study was conducted on May - September 2020 at the Laboratorium of Cell Culture and Cytogenetic of Padjajaran University, Bandung. This study used a Randomized Complete Block Design (RCBD) with three repetitions. MCF-7 cells line used in this study were from American Type Cultural Collection (ATCC), and cultured used RPMI 1640 Medium with $80-90 \%$ confluent.

\section{Cell Culture}

The cells were culture by Roswell Park Memorial Institue Medium (RPMI) 1640. This media was supplemented with $10 \%$ Fetal Bovine Serum (FBS), GibcoTM (Thermo Fisher Scientific Cat.26140-079), and 0,2 mL bovine insulin (Sigma Aldrich Cat. No. 15500 and CAS RN 11070-73-8) at 37o C in $5 \% \mathrm{CO}_{2}$. The thawing process was performed in the waterbath at $37^{\circ} \mathrm{C}$ for $2-4 \mathrm{~min}$. Then, $5 \times 10^{4}$ cell was taken into T-flask and incubated at $37^{\circ} \mathrm{C}$ in $\mathrm{CO}_{2} 5 \%$. When cells density reached $80 \%$ confluently, the trypsinization was done using $0,25 \%$ trypsin+0,53mM EDTA solution and then subcultured into new culture vessels, also incubated at $37^{\circ} \mathrm{C}$ in $\mathrm{CO} 25 \%$. After two times passaging, the MCF-7 cells are ready to be treated.

The ethanolic extract of Annonaceous was exposed to MCF-7 cells line while confluent of the medium was $80-90 \%$. The extract was dissolved in $1 \mathrm{ml}$ of DMSO with a concentration of $0.1 \%$. Furthermore, dilution was made with a dose of $0 \mu \mathrm{g}$ / $\mathrm{ml}(\mathrm{K}) ; 25 \mu \mathrm{g} / \mathrm{ml}(\mathrm{P} 1) ; 50 \mu \mathrm{g} / \mathrm{ml}$ (P2); $100 \mu \mathrm{g} / \mathrm{ml}$ (P3); $200 \mu \mathrm{g} / \mathrm{ml}$ (P4). Cells were incubated for 48 hours after treatment. Supernatant after 48 hours incubation was incubated in microwell coated by VEGF antibodies and incubation for 1 hour. After the incubation, Horse Radish Peroxidase (HRP) samples were given and incubated 30 minutes more. TMB was added to the sample, and the sample ready to analyze used ELISA methods with $\lambda=405 \mathrm{~nm}$.

\section{Statistical Analysis}

Comparison of mean values between treatments are presented as mean \pm SD and analyzed using ANOVA followed by LSD test with a 95\% confidence level.

\section{RESULTS}

The results of ELISA analyze shows that any decreased of TGF- $\beta$ expression on sample with treatment on some concentration ethanolic extract of Annonaceous. Table 1 show the result of TGF- $\beta$ expression analyze with 1 control $(0 \mathrm{ng} / \mathrm{mL})$ and 4 sample with different concentration (25 $\mu \mathrm{g} / \mathrm{mL}, 50 \mu \mathrm{g} / \mathrm{mL}, 100 \mu \mathrm{g} / \mathrm{mL}, 200 \mu \mathrm{g} / \mathrm{mL}$ ). The result show $(25 \mu \mathrm{g} / \mathrm{mL}, 50 \mu \mathrm{g} / \mathrm{mL}, 100 \mu \mathrm{g} / \mathrm{mL}, 200 \mu \mathrm{g} / \mathrm{mL})$ 
concentration of ethanolic extract of Annonaceous have decreasing the TGF- $\beta$ expression $(p<0,05)$.

Table 1. The mean level of TGF- $\beta$ in the MCF-7 breast cancer cell line treated with Annonaceous sp. Ethanolic Extract for 48 hours with different concentrations

\begin{tabular}{lll}
\hline EEDS Concentration & $\begin{array}{l}\text { TGF-B } \\
\text { (Mean } \pm \text { SD) }\end{array}$ & P value \\
& $79,33 \pm 2.96$ & \\
\hline$\mu \mathrm{g} / \mathrm{mL}$ & $42,09 \pm 0,01$ & 0.001 \\
$25 \mu \mathrm{g} / \mathrm{mL}$ & $31.33 \pm 1.45$ & \\
$50 \mu \mathrm{g} / \mathrm{mL}$ & $25.33 \pm 4.70$ & \\
$100 \mu \mathrm{g} / \mathrm{mL}$ & $11.67 \pm 1.67$ & \\
$200 \mu \mathrm{g} / \mathrm{mL}$ & &
\end{tabular}

\section{DISCUSSION}

In recent years, many systems biology approaches have been used with various cancers. The materials described here can build bases to discover novel cancer therapy targets in connection with computer-aided drug design (CADD). In general, anti-cancer agents have a narrow therapeutic window. Therefore it is needed to analyze on cellulars-level to develop an anti-cancer agent to determine the lowest concentrations that have therapeutic effects. ${ }^{18,19}$

Angiogenesis is an essential step for breast cancer progression and dissemination. The development of new blood vessels in a cancer setting (angiogenesis) is conducted by numerous physiological and pathological stimuli, where the primary stimulus is hypoxia. ${ }^{15}$ Acetogenin has known the potential effect as an anti-cancer agent. Our previous research shows that these compounds can trigger apoptosis and inhibit the proliferation of MCF-7 breast cancer line cells. ${ }^{20}$

The results of this study showed that administration of the ethanolic extract of Annonaceous for 48 hours was able to decrease TGF- $\beta$ expressions of breast cancer cells MCF-7 cells line by significantly in some different concentrations (Table 1).

Acetogenins (ACG) are naturally occurring compounds that are chemically one of the least investigated families. Mangal et al. (2016) have observed that the relative potency of acetogenins can be categorized as adjacent bis-THF ACGs > nonadjacent bis-THF ACGs > mono-THF ACGs > linear-THF ACGs. Among adjacent bis-THF ACGs, asiminocin (A100), asiminecin (A101), asiminacin (A102), and asimin (A103) are the most active compounds with in-vitro activity (ED50) in the range of $10-9$ to $10-12 \mu \mathrm{g} / \mathrm{mL}^{21}$

Transforming Growth Factor- $\beta$ (TGF- $\beta$ ) is a member of the polypeptide family of growth factors. Loss of inhibitory ability of TGF- $\beta$ and increased expression of this compound has been linked to the progression and malignancy of breast cancer. ${ }^{22}$ TGF- $\beta$ is a cytokine that is overexpressed in breast cancer and is closely related to the size of the tumor mass, tumor stage, and lymph node metastases. The research conducted by Tyasmara \& Sandhika (2018) has shown that the expression of TGF- $\beta$ can be used as a biomarker to predict the progressivity and prognosis of breast cancer. ${ }^{23}$

Transforming Growth Factor- $\beta$ (TGF- $\beta$ ) supports tumor progression by stimulating the differentiation process of cancer epithelial cells into migratory mesenchymal cells, encouraging cancer cells to become invasive and move to a location far from their parent, encouraging angiogenesis and mediating the avoidance of cancer cells from the body's immune system. ${ }^{22,24}$ Transforming Growth Factor- $\beta$ (TGF- $\beta$ ) is a potent inhibitor of average epithelial cell growth. However, experimental studies have shown that TGF- $\beta$ can promote tumor-host interactions that indirectly foster cancer cell development. When the TGF-B function changes during the epithelial cell transformation process are still unknown. Recent evidence suggests that TGF-B autocrine signaling is operational on some tumor cells and can also contribute to malignancy and metastases regardless of the effect on non-tumor cells. The process of epithelial tumor infiltration is often caused by epithelial-to-mesenchymal transition (EMT), downregulation of molecular cell adhesions, increased metalloprotease expression and increased motility and angiogenesis, all of which can be modulated by TGF-B. ${ }^{25}$

There are three approaches to inhibiting TGF- $\beta$ expression, using an antisense molecule to prevent the synthesis of TGF$\beta$ at the ligand level. The ligand is the first component of a pathway. Therefore, many studies targeting transcription products of the TGF- $\beta$ coding gene to inhibit TGF- $\beta$ synthesis have been carried out. Gene Silencing by RNA Interference (RNAi) technique allows regulation of a gene expression. SRNAi technology is based on small RNA molecules: micro interfering RNA (miRNA) and short interfering RNA (siRNA). This micro molecule works by binding to a specific mRNA sequence; therefore, preventing translation through this pathway can suppress the expression of the TGF- $\beta$ gene. Binding of Antisense Oligonucleotides (ASO) to RNA and targeting TGF- $\beta$ mRNA allows inhibition of the TGF- $\beta$ gene. Currently, Antisense Pharma is conducting phase I / II clinical trials on pancreatic neoplasms, melanomas, and colorectal neoplasms using intravenous administration, which has shown good effectiveness. The second is through blocking ligand-receptor interactions using ligand traps (monoclonal antibodies and receptors) and using antireceptor monoclonal antibodies, which aim to inhibit cascade signaling at the intracellular level (with the use of TGF- $\beta$ receptor kinase inhibitors and peptide aptamers). ${ }^{12}$

Several studies using soursop leaf extract to evaluate TGF- $\beta$ expression have been carried out, in a study conducted by (El Tawiil et al., 2020) showed that the ethanol extract of soursop leaves could reduce the expression of TGF- $\beta$ from $66.8 \pm 3.8$ to $31.6 \pm 3.4$ with a statistical significance value of $\mathrm{p}<0.0001$ at a dose of $50 \mathrm{mg} / \mathrm{kg} \mathrm{BW} /$ day. ${ }^{26}$ These results were not much different from the combination therapy of soursop leaf extract and low dose radiation with an expression value of $28.7 \pm 2.5$. Furthermore, the soursop leaf extract is thought to induce the G1 and G2 / M cell cycles and inhibit DNA synthesis. TGF- $\beta$ is also known to control cell proliferation primarily by inhibiting cell cycle progression through G1 capture, by inducing or activating CDK inhibitors such as p16INK4A, p15INK4B, p21CIP1, and p27Kip1.27

\section{CONCLUSIONS}

The ethanolic extract of Annonaceous has shown the potential to decrease TGF- $\beta$ level on MCF-7 cells line. In addition, there are needed to investigate the decrease of TGF- $\beta$ by molecular study.

\section{Conflict of interest}

The author declares no conflict of interest in this study. 


\section{REFERENCES}

1. Momenimovahed Z, Salehiniya H, "Epidemiological Characteristics of and Risk Factors for Breast Cancer in the World" Breast Cancer, 2019; 11:151-64. https://doi.org/10.2147/BCTT.S176070

2. Bray F, Ferlay J, Soerjomataram I, Siegel RL, Torre LA, Jemal A, "Global Cancer Statistics 2018: GLOBOCAN Estimates of Incidence and Mortality Worldwide for 36 Cancers in 185 Countries" CA Cancer J Clin, 2018; 68(6):394-424. https://doi.org/10.3322/caac.21492

3. WHO, "Who Report on Cancer", Geneva: World Health Organization; 2020.

4. Komite Penanggulangan Kanker Nasional, "Panduan Penatalaksanaan Kanker Payudara", Jakarta: Kementeri Kesehat RI; 2015.

5. WHO, "Breast cancer", Geneva: WHO; 2018.

6. Karsono R, Purwanto DJ, Haryono SJ, Karsono B, Sari L, Pratiwi Y, et al., "Preoperative Neoadjuvant Hormonal Therapy and Neoadjuvant Chemotherapy for Stage 3B and 4 Breast Cancer Patients in Dharmais Hospital-National Cancer Center, Indonesia: A Cohort Study" Indones J Cancer, 2019;12(4):10915. https://doi.org/10.33371/ijoc.v12i4.604

7. Esquivel M, Ostoa-Saloma P, Palacios-Arreola MI, Nava-Castro KE, Castro JI, Morales-montor J, "The Role of Cytokines in Breast Cancer Development and Progression" J Interferon Cytokine Res, 2014; 35(1):1-16. https://doi.org/10.1089/jir.2014.0026

8. Kurnijasanti R, Hamid IS, Rahmawati K, "Efek Sitotoksik In Vitro dari Ekstrak Buah Mahkota Dewa (Phaleria macrocarpa) Terhadap Kultur Sel Kanker Mieloma" J Penelit Med Eksakta, 2008; 7(1):48-54.

9. Desai A, Qazi G, Ganju R, El-Tamer M, Singh J, Saxena A, et al., "Medicinal Plants and Cancer Chemoprevention" Curr Drug Metab, 2008: 9(7):581-91. https://doi.org/10.2174/138920008785821657

10. Sukohar A, Herawati H, Witarto AB, Setiawan, Wirakusumah FF, Sastramihardja HS, "Role of Chlorogenic Acid from Lampung Robusta Coffee Against Gene Expression of Mirna (Micro Rna) 146 A on Hepatocellular Carcinoma Cells" IJPRNS, 2013; 2(6):776-84

11. Hamizah S, Roslida AH, Fezah O, Tan KL, Tor YS, Tan CI, "Chemopreventive potential of Annona muricata L leaves on chemically-induced skin papillomagenesis in mice" Asian Pacific J Cancer Prev, 2012; 13(6):2533-9. https://doi.org/10.7314/APJCP.2012.13.6.2533

12. El Tawil GA, Noaman EA, Askar MA, El Fatih NM, Mohamed HE, "Anticancer and Apoptogenic Effect of Graviola and Low-Dose Radiation in Tumor Xenograft in Mice" Integr Cancer Ther, 2020; 19:1-12. https://doi.org/10.1177/1534735419900930

13. Li N, Shi Z, Tang Y, Chen J, Li X, "Recent progress on the total synthesis of acetogenins from Annonaceae" Beilstein Journal of Organic Chemistry, 2008; 4(48):1-62. https://doi.org/10.3762/bjoc. 4.48
14. González MC, Tormo JR, Bermejo A, Zafra-Polo MC, Estornell E Cortes D, "Rollimembrin, a novel acetogenin inhibitor of mammalian mitochondrial complex I" Bioorganic Med Chem Lett, 1997; 7(9):1113-8. https://doi.org/10.1016/S0960894X(97)00171-6

15. Longatto Filho A, Lopes JM, Schmitt FC, "Angiogenesis and Breast Cancer" J Oncol, 2010; 2010:1-7. https://doi.org/10.1155/2010/576384

16. Ferrara N, "Vascular endothelial growth factor" Arterioscler Thromb Vasc Biol, 2009; 29(6):789-91. https://doi.org/10.1161/ATVBAHA.108.179663

17. Brown KA, Aakre ME, Gorska AE, Price JO, Eltom SE, Pietenpol JA, et al., "Induction by transforming growth factor- $\beta 1$ of epithelial to mesenchymal transition is a rare event in vitro" Breast Cancer Res, 2004; 6(3):215-31. https://doi.org/10.1186/bcr778

18. Wong YH, Chiu CC, Lin CL, Chen TS, Jheng BR, Lee YC, et al., "A New Era for Cancer Target Therapies: Applying Systems Biology and Computer-Aided Drug Design to Cancer Therapies" Current Pharmaceutical Biotechnology, 2016; 17(14):1246-67. https://doi.org/10.2174/1389201017666161019160606

19. Stegmeier F, Warmuth M, Sellers WR, Dorsch M, "Targeted Cancer Therapies in the Twenty-First Century: Lessons From Imatinib" Clin Pharmacol Ther, 2010; 87(5):543-52. https://doi.org/10.1038/clpt.2009.297

20. Muhartono, Subeki, Hanriko R "Mucoxin (Acetogenin) Reduces Proinflammatory Cytokines in Breast Cancer" Biomed Pharmacol J, 2019;12(1):479-83. https://doi.org/10.13005/bpj/1664

21. Mangal M, Imran Khan M, Mohan Agarwal S, "Acetogenins as Potential Anti-cancer Agents" Anticancer Agents Med Chem, 2015: 16(2):138-59. https://doi.org/10.2174/1871520615666150629101827

22. Drabsch Y, Ten Dijke P, "TGF- $\beta$ signaling in breast cancer cell invasion and bone metastasis" J Mammary Gland Biol Neoplasia, 2011; 16(2):97-108. https://doi.org/10.1007/s10911-0119217-1

23. Tyasmara A, Sandhika W, "Comparison of TNF- $\alpha$ and TGF- $\beta$ Expression in Breast Cancer Tissues-with and without Axillary Lymph Node Metastasis" Indones J Cancer, 2018;12(1):1-5 https://doi.org/10.33371/ijoc.v12i1.548

24. Xu J, Lamouille S, Derynck R, "TGF-B-induced epithelial to mesenchymal transition" Cell Research, 2009; 19(2):156-72. https://doi.org/10.1038/cr.2009.5

25. Dumont N, Arteaga CL, "Targeting the TGF $\beta$ signaling network in human neoplasia" Cancer Cell, 2003; 3(6):531-6. https://doi.org/10.1016/S1535-6108(03)00135-1

26. Sheen YY, Kim MJ, Park SA, Park SY, Nam JS, "Targeting the transforming growth factor- $\beta$ signaling in cancer therapy" Biomol Ther, 2013; 21(5):323-31. https://doi.org/10.4062/biomolther.2013.072 